\title{
Occurrence of microfungi as litter colonizers and endophytes in varied plant species from the Western Ghats forests, Goa, India
}

\author{
D'Souza MA* and Bhat DJ'
}

\author{
* Department of Botany, Dhempe College of Arts \& Science, Miramar, Goa-403 002, India \\ Email:majorinal@ rediffmail.com \\ ${ }^{1}$ Department of Botany, Goa University, Goa-403 206, India
}

D'Souza MA, Bhat DJ 2013 - Occurrence of microfungi as litter colonizers and endophytes in varied plant species from the Western Ghats forests, Goa, India. Mycosphere 4(3), 567-582, Doi $10.5943 /$ mycosphere/4/3/10

\begin{abstract}
In this study 30 widely distributed plant species from the Western Ghat forest in Goa were randomly selected and were studied with regard to their fungal association as endophytes and litter colonizers. This effort resulted in the recovery of more than 6500 isolates of microfungi which were assignable to 675 species of fungi belonging to 275 genera which included properly recognized Mucorales(1), Ascomycetes (18), Hyphomycetous asexual fungi (289), Coelomycetous asexual fungi (22) and undetermined taxa (77), besides a sizable number of non-sporulating forms (268). Species of endophytes (53) and litter colonizers (77) were selected for enzyme studies. Ten taxa occurred both as endophytes and litter colonizers. Endophytes and litter colonizers showed different enzyme profiles indicating that habit and habitat dictated enzyme activity. Several recovered fungi were new to science and some have already been described as new species and are elaborated here in this paper. Some taxa showed substrate specificity others were diverse in their distribution. Not a single taxon was found to occur on all 26 plant species and only three taxa showed more than $50 \%$ association with all the 26 plant species. This shows evidence towards substrate preference in fungi in relation to their host plants.
\end{abstract}

Key Words - Asexual fungi - biodiversity - microfungi - taxonomy

\section{Introduction}

Litter and endophytic microfungi are found to occur in virtually every plant on earth and have been isolated from all plants studied to date. Bills and Polishook, 1994 have shown that tropical plants harbours diverse fungi in abundance than the temperate plants while studying the microfungi associated with leaf litter of a lowland rain forest in Costa Rica and Puerto Rica (Polishook et. al,. 1996). A considerable amount of work has been done on saprobic fungi (Hyde $e t$ al., 2007). Endophytes in particular are found on plants range from Large trees (Gonthier et. al., 2006; Oses et al., 2008), palms (Fröhlich et al., 2000; Taylor and Hyde, 2003), grasses (Sanchez et al., 2007), sea grasses (Alva et al., 2002), and even lichens (Li et al., 2007). Endophytes have been characterized and studied by different workers since then various definitions have been proposed (Hyde and Soytong, 2008). Several recent studies have explored the role of endophytes and their significance both from the temperate and tropical regions (Redlin and Carris, 1996; Arnold et al., 
2000; Arnold, 2007; Suryanarayan and Kumaresan, 2000; D’Souza and Bhat, 2007). Similarly there are reviews on fungal endophytes adding to our knowledge on endophytes (Ghimire and Hyde, 2004; Hyde and Soytong, 2008). Fungi can decompose complex carbon and nitrogen compounds such as cellulose, hemicellulose, lignin, pectins, proteins, humic acids, and many other substances, by releasing of extracellular enzymes (Jennings, 1989, 1995; Kjøller \& Struwe, 1992; Moore-Landecker, 1996). According to Bills, 1995 and Bills, 1996 tropical forests are the 'black box' with respect to our knowledge on diversity and distribution of microfungi and would offer new and exciting opportunities for all interested in fungal ecology, taxonomy and biotechnology. With this view the present study was therefore undertaken to document both the litter and endophytic mycota associated with monocotyledonous and dicotyledonous plant species from the Western Ghats forests in Goa, India, their substrate specificity with regards to the host plants and to determine the significance of the isolated fungal strains with regard to production of enzymes.

\section{Materials and Methods}

Two types of samplings were done during this study.

(i) For taxonomy and diversity study of the litter and endophytic fungi, sampling materials of both dicotyledonous and monocotyledonous plants were randomly gathered from different sites in the forest. In the first category, aimed at documentation of fungal diversity of the region, specimens of twenty six several widely distributed native dicotyledonous and monocotyledonous plant species were randomly gathered from forests of places such as Alorna, Baga, Bondla, Chorlem, Cotigao, Molem, Taleigao and Tambisurla of Goa state and were scanned for litter inhabiting (epiphytic) and endophytic fungi i.e. Bambusa arundinacea (Retz.)Willd., Bauhinia purpurea Linn., Calamus thwaitesii Becc. Ex Hook., Caryota urens Linn., Curcuma decipens Dalz., Dellenia indica Linn., Dendrocalamus strictus (Roxb.) Nees, Hydnocarpus laurifolia (Dennst.) Sleumer, Terminalia paniculata Roth., Elaeis guineensis Jacq., Ensete superbum (Roxb.) Cheesman, Ficus religiosa Linn., Ficus benghalensis Linn., Ficus tinctorius var. parasitica (Willd.) Corner, Flacourtia montana Graham, Helictris ixora Linn., Ixora brachiata Roxb., Mangifera indica Linn., Pandanus tectorius Soland. Ex Parkinson, Psychotria dalzelli Hk.f., Sageraea laurifolia (Grah.) Blatter, Syzygium cumini (Linn.) Skeels, Tectona grandis Linn., Xylia xylocarpa (Roxb.) Taub., Zanthoxylum rhetsa (Roxb.) DC., and Sanseiviera zeylanica Willd.

(ii) In the second, aimed at elucidation of seasonal occurrence of fungi,

samples of four pre-determined plants were gathered from two defined localities, Bondla and Molem, at regular seasonal intervals, over a period of two years. Seasonal studies were carried out during the pre-monsoon, monsoon and post-monsoon season with following native dicotyledonous and monocotyledonous plant species, one plant each from Bondla and Molem wildlife sanctuaries.

A. Bondla wildlife Sanctuary:

Dicotyledonous representative: $\quad$ Saraca asoca (Roxb.) De Wilde

Monocotylednous plant:

B. Molem wildlife Sanctuary:

Dicotyledonous representative: Careya arborea Roxb.

Monocotylednous plant: Dendrocalamus strictus (Roxb.) Nees

The sampling locations are indicated in Fig. 1. The two sites of seasonal study are well recognized sanctuaries stretched along the Western Ghats in Goa State. The Bondla Wildlife Sanctuary, an area of 8 sq.km and smaller of the two, is located about $55 \mathrm{~km}$ north-east of Goa University campus. The vegetation in the region is largely moist deciduous with small patches of evergreen trees covered by stranglers, lianas and canes. The Molem Wildlife Sanctuary, about $240 \mathrm{sq}$. km area along the eastern side of the State, is the largest sanctuary in Goa. The vegetation ranged from moist-deciduous and semi-evergreen to evergreen type. At several places in the sanctuary one would notice good under storey cover of shrubs. 


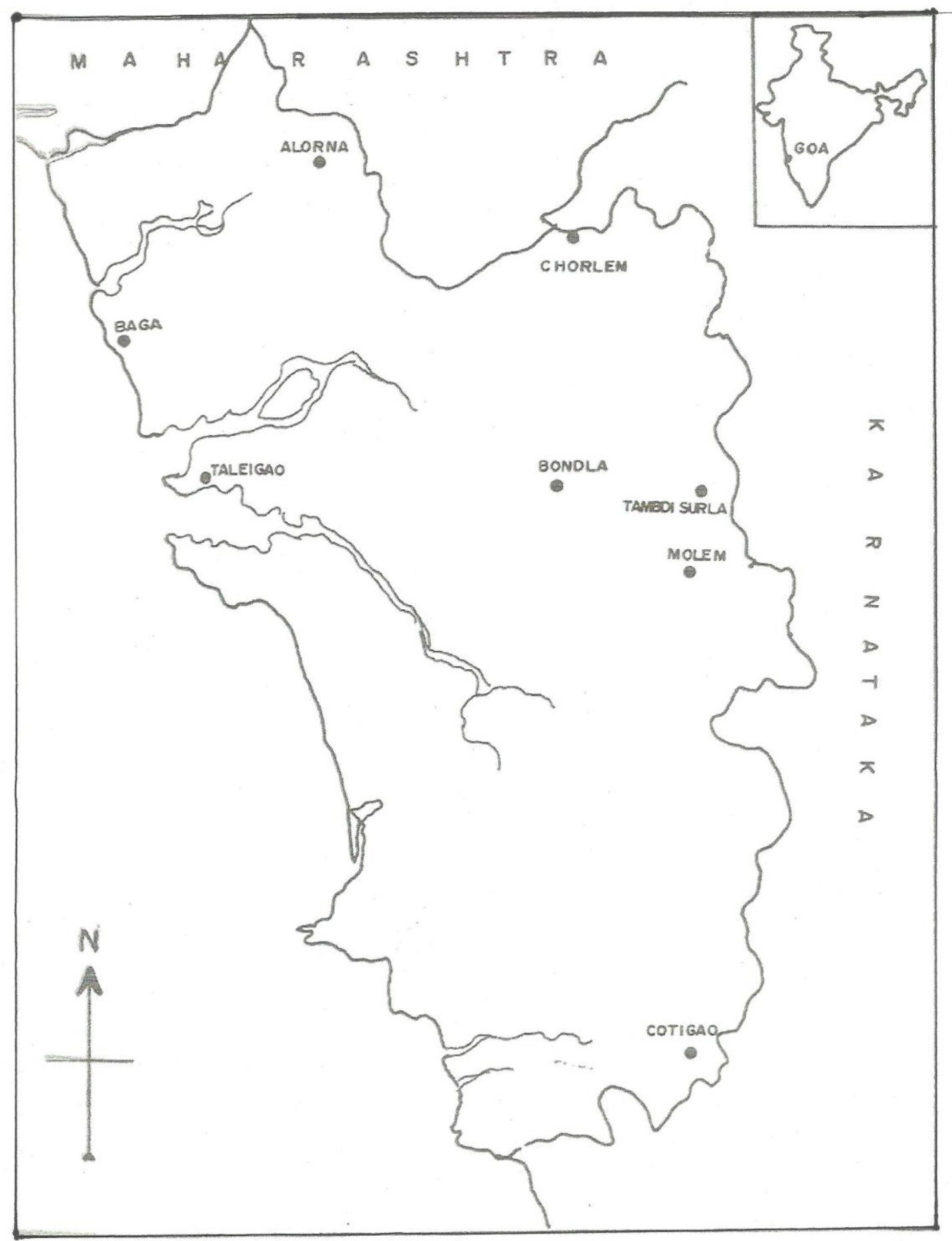

Fig. 1 - Map showing the sampling sites

Being in the tropical belt and proximity of the west coast, ambient temperature of the collection sites in the Western Ghats in Goa state always ranged between $22-35^{\circ} \mathrm{C}$, the temperature seldom falling below $16^{\circ} \mathrm{C}$. Mean annual rainfall along the ghats was $220-300 \mathrm{~cm}$ and humidity ranged between $60-90 \%$.

The sampling materials included the following:

a) Senescent or dried leaves fallen to the ground and exposed to a prolonged time of decay. These leaves were generally blackish brown, brittle and sometimes had no interveinal laminar regions.

b) Dead and decaying, fallen twigs, culms, spathe, etc., and

c) Intact fresh, green, disease free and healthy leaves, twigs etc. 
The leaf litter, twigs and live leaves, twigs were sampled out at random during the study period and analyzed for litter and endophytic fungi. The samples were transported to the laboratory in fresh polythene bags and stored in a refrigerator at $4^{0} \mathrm{C}$ until they were processed.

\section{Isolation Methods}

In the studies of litter and phylloplane fungi, simultaneous use of more than one isolation techniques has been found advantageous in the understanding of microbial population (Dickinson, 1976; Dickinson and Wallace, 1976; Hyde and Soytong, 2008). A combination of various conventional (e.g., moist chamber, particle plating) and molecular techniques appears to be the more promising approach for characterizing the fungal community structure and for filling the gaps in our knowledge of the contribution of fungal groups to the decomposition of leaves in a forest ecosystem. In the present study, two kinds of isolation techniques, namely 'moist chamber incubation' (Hawksworth, 1974) and 'particle-plating' (Bills and Polishook, 1994) methods were used in order to accomplish maximum recovery of litter fungi associated with the plant substrate. The endophytic fungi were isolated by employing ' 3 -step surface sterilization process' elaborated by Petrini and Fisher (1986). Incubation was done at $22-25^{\circ} \mathrm{C}$ and fungi were isolated on $2 \%$ MEA plates, a general medium commonly used in endophyte studies (Arnold, 2000) and known to yield large number of endophytic isolates and species relative to other media (Frohlich \& Hyde, 1999). Isolations were carried out at room temperature with the help of a stereoscope fitted with an incident light. The fungal colonies emerging out from the litter particles and leaf or twig segments in the isolation plates were counted as 'colony forming units'(CFU). Each such isolated distinct fungal colony was considered as a 'morphotype'. The isolates were grouped into sporulating and non-sporulating forms. Sporulating structures were considered as diagnostic characters in the identification of fungi. Semi-permanent slides of sporulating structures from the colonies were prepared using water or lactophenol cotton blue as mountant (Hawksworth, 1974). Illustrations of the fungi were made using a camera-lucida drawing tube attached to a binocular microscope (Olympus Make). Photomicrographs were taken using an automatic camera fitted to a bright-field research microscope (Nikon Make). Using standard taxonomic keys and monographs, (Ellis, 1971; Ellis, 1976; Sutton, 1980; Matsushima, 1971; Matsushima, 1975), the isolates were identified and assigned to respective genera and species. In the absence of sporulation, the taxonomic identity of several non-sporulating forms recovered is not known at this moment and they are recognized merely based on cultural characters such as colony morphology, growth rate and pigmentation. For enzyme assays, the methods prescribed by Carder (1986) for amylase and Hankin and Anagnostakis (1975) for cellulose and pectinase were followed.

\section{Data Analysis}

The relative frequency was calculated using the formula, $\left(R_{f}=n / N \times 100\right.$, where $n=$ number of fungal colonies of one species in a collection, $\mathrm{N}=$ total number of fungal colonies of all species in the same collection). The mean density of colonization of a single endophyte species was calculated by method of Fisher and Petrini (1987), [i.e. the number of colonized segments divided by the total number of segments plated x 100]. In case of seasonal occurrence of microfungi, Jaccard Similarity Coefficients were calculated for all possible pairs of hosts to compare the endophyte assemblages, according to the following formula.

Similarity coefficient $=\mathrm{C} /(\mathrm{A}+\mathrm{B}+\mathrm{C})$,

Where $\mathrm{A}$ and $\mathrm{B}$ are the total number of fungal species isolated from any two hosts and $\mathrm{C}$ the number of fungal species found in common (Sneath and Sokal, 1973). The results were expressed in percentages.

In order to analyze the enzyme activity, Euclidean distance average linkage method of cluster analyses using Systat 5.1 was used. 


\section{Results}

\section{Biodiversity}

In the present study, investigation on microfungi occurring in association with 30 monocotyledonous and dicotyledonous native plants (Tables 1,2) of forests of Western Ghats in Goa was carried out over a period of two years following moist-chamber incubation, particleplating and endophyte isolation techniques. The exercise resulted with recovery of more than 6500 isolates of microfungi. These were assignable to 675 taxa of fungi belonging to 275 genera which included properly recognized Mucorales (1), Ascomycetes (18), asexual hyphomycetes (289), asexual coelomycetes (22) and undetermined taxa (77), besides a sizable number of nonsporulating forms (268).

In case of diversity study, with regard to 26 plants species studied, the study resulted with recovery of 388 microfungi. They belonged to major taxonomic groups such as asexual hyphomycetes (224), Ascomycetes (14), asexual coelomycetes (20), besides non-sporulating morphotypes (130). In case of seasonal studies, in all, a total of 4461 isolates distinguishable into 402 taxa of litter and endophytic fungi belonging to Zygomycetes (1), Ascomycetes (12), asexual coelomycetes (14), asexual hyphomycetes (209) and non-sporulating forms (166) were recovered. As can be seen from diversity and seasonal study, hyphomycetous asexual fungi are largest group along with sizeable number of non-sporulating forms. Amongst the fungi brought into pure culture, some fungi did not sporulate and these were considered here as 'non-sporulating morphotypes' (NSM) based on cultural characters such as colour, shape, growth rate and presence and absence of exudates in the colony. In the absence of any sporulating structures the taxonomy of these forms also remained undetermined. Taxonomic details are given in Table $1 \&$ Table 2 . In the descending order of abundance, the fungi associated with plant species were in this order: asexual hyphomycetous asexual fungi and non-sporulating forms (maximum) and coelomycetous sexual fungi and ascomycetes (minimum). It is evident from the results that fungi belonging mainly to hyphomycetous asexual group and non-sporulating forms were the major colonizers of the litters of plant species as exhibited by their species abundance. Of the plants studied, in monocotyledons, the recovery percent ratio of hyphomycetous asexual fungi was $88 \%$ and non-sporulating forms $12 \%$. In dicotyledonous plants, the recovery percent ratio of hyphomycetous asexual fungi and nonsporulating forms was 70:30.

In order to compare the similarity of species composition of fungi between host plants, the data on number of fungal species recovered from each plant was subjected to Jaccard's similarity coefficient analysis. The Jaccard's similarity coefficient showed that the composition of fungi recovered from two plant species, i.e. Calamus thwaitesii and Saraca asoca did not overlap by more than $27.05 \%$ and the other two plant species, i.e. Careya arborea and Dendrocalamus strictus by $21.19 \%$, though these plants, i.e. Calamus thwaitesii and Saraca asoca in Bondla wildlife sanctuary and Careya arborea and Dendrocalamus strictus in Molem wildlife sanctuary, lie in proximity to each other and were practically exposed to the same environmental conditions and fungal inoculums. (Table 4).

Table 1 Fungi isolated from four plants during seasonal study

\begin{tabular}{|c|c|c|c|c|c|c|c|c|c|c|}
\hline \multirow[t]{2}{*}{ Plant species } & \multicolumn{2}{|c|}{ Mucorales } & \multicolumn{2}{|c|}{ Ascomycete } & \multicolumn{2}{|c|}{ Coelomycete } & \multicolumn{2}{|c|}{ Anamorphic } & \multicolumn{2}{|c|}{$\begin{array}{c}\text { Non- } \\
\text { sporulating }\end{array}$} \\
\hline & $\overline{\mathrm{Li}}$ & $E n$ & $\overline{L i}$ & $E n$ & $\overline{L i}$ & $E n$ & $\overline{L i}$ & $E n$ & $\overline{\mathrm{Li}}$ & $E n$ \\
\hline Saraca asoca & 0 & 0 & 6 & 4 & 9 & 6 & 63 & 10 & 50 & 11 \\
\hline Calamus thwaitesii & 0 & 0 & 4 & 2 & 6 & 3 & 87 & 12 & 39 & 10 \\
\hline Careya arborea & 1 & 0 & 6 & 2 & 12 & 2 & 82 & 4 & 43 & 19 \\
\hline $\begin{array}{l}\text { Dendrocalamus } \\
\text { strictus }\end{array}$ & 0 & 0 & 2 & 2 & 4 & 1 & 82 & 13 & 52 & 14 \\
\hline
\end{tabular}

(Note: Substrates: $L i$ - Leaf-litter; En-Endophyte) 


\section{Substrate specificity}

Generally, different plant species have a different chemical composition, and this may affect the microbial community composition and biomass. As can be seen from the results, it is evident that a diverse and large number of microfungi were isolated from different plant substrates. Some fungi showed substrate specificity others were diverse in their distribution.

With regard to plant substrate, live or dead, the number of fungi (both litter inhabiting and endophytes) appeared were common to most of the plant species studied while a few were restricted to specific plants. Not a single fungus was found to occur in all the 26 plant species scanned. Amongst the fungi recorded, only three showed more than 50\% association with plant species. That is, Cladosporium herbarum was found to occur on 20 plant species, viz. Dendrocalamus strictus, Bambusa arundinacea, Bauhinia purpurea, Calamus thwaitesii, Caryota urens, Curcuma decipens, Dellenia indica, Hydnocarpus laurifolia, Elaeis guineensis, Ficus religiosa, Ficus benghalensis, Flacourtia montana, Helictris ixora, Ixora brachiata, Mangifera indica, Psychotria dalzelli, Syzygium cumini, Tectona grandis, Xylia xylocarpa and Zanthoxylum rhetsa whereas Vermiculariopsiella elegans was common to the 17 plants: Bambusa arundinacea, Bauhinia purpurea, Calamus thwaitesii, Curcuma decipens, Dendrocalamus strictus, Elaeis guineensis, Ensete superbum, Flacourtia Montana, Ficus religiosa, Ficus benghalensis, Helictris ixora, Hydnocarpus laurifolia, Mangifera indica, Pandanus tectorius, Psychotria dalzelli, Sanseiviera zeylanica and Zanthoxylum rhetsa. Cochcliobolus lunatus was common to following 17 plants: Bambusa arundinacea, Calamus thwaitesii, Caryota urens, Dendrocalamus strictus, Ensete superbum, Ficus tinctorius var. parasitica, Ficus religiosa, Helictris ixora, Hydnocarpus laurifolia, Mangifera indica, Pandanus tectorius, Psychotria dalzelli, Syzygium cumini, Tectona grandis and Zanthoxylum rhetsa.

The following fungi showed more than $50 \%$ association with the plants studied: Cladosporium herbarum (84.61\%), Cochliobolus lunatus $(65.38 \%)$ and Vermiculariopsiella elegans $(65.38 \%)$. It may be inferred that these plants are major substrate or hosts for the fungi. The fungi such as Acremonium sp.1, Cladosporium cladosporoides, Cylindrocladium sp., Dactylella sp., Dictyochaeta assamica, Fusarium decemcellulare, Fusarium solani, Idriella lunata, Penicillium sp. Trichoderma lignorum and Undetermined Ascomycete sp. 3 showed association with less than $50 \%$ of the plants studied. Table 3.

The common and exclusive genera found in the plant species are listed in the Fig. 2 and

As seen in Fig 2, a few of the fungi recovered were isolated more than once but from the same plant and some were found to occur on more than one plant species during the course of study period. It has been observed that these fungi were specific to the plant host and did not occur on any other plants. It may be presumed that these fungi do not colonize other plants and their occurrence is limited to only one or a few plant species. Such substrate specificity in plants by fungi was predicted by Boddy and Griffith (1989); Whalley (1993); Zhou and Hyde, 2001 and the results presented here were in conformity.

\section{New described fungi}

Several recovered fungi were new to science and have been already described as new species. i.e.

1. Aquaphila ramdayalea Maria et Bhat sp. nov., Kumbhamaya goanensis Maria et Bhat sp. nov. (DSouza and Bhat, 2001)

2. Bharatheeya gen.nov., Bharatheeya goanensis (Bhat and Kendrick) D'Souza and Bhat. comb.nov., Bharatheeya mucoidea sp. nov (DSouza and Bhat, 2002)

3. Kramasamuha kamalensis Maria et Bhat sp. nov. (Maria and Bhat, 2002)

4. Didymobotryum spirillum D'Souza et Bhat sp. nov. (D'Souza and Bhat, 2002)

5. Trichobotrys ramosa Maria et Bhat sp. nov. (DSouza and Bhat, 2001)

6. Vermiculariopsiella elegans sp. nov. and Vermiculariopsiella inidica sp. nov. (Keshavaprasad et. al., 2003) 
7. Pleurophragmium indicum M. A. D'Souza \& Bhat, sp. nov. (Maria A. D’Souza \& D.J. Bhat, 2012)

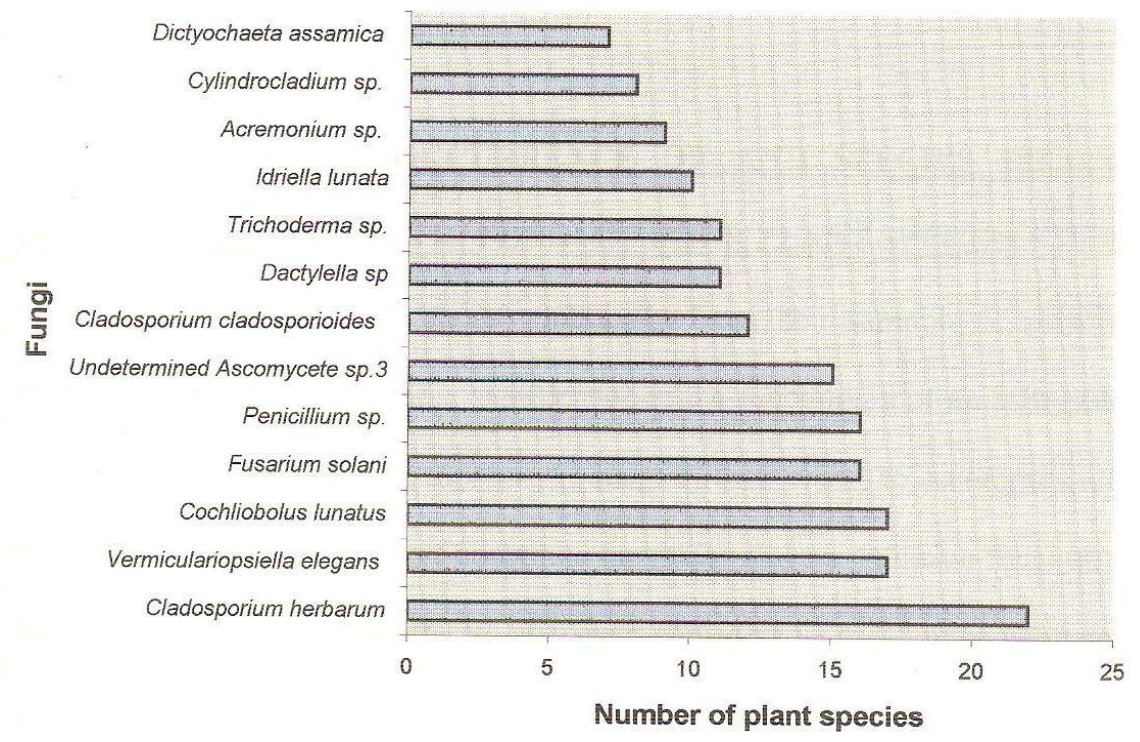

Fig. 2 - Occurrence of fungi on plant species

Table 2 Fungi isolated from different dicotyledonous and monocotylednous plants during the diversity study:

\begin{tabular}{|c|c|c|c|c|c|c|c|c|c|}
\hline \multirow[t]{2}{*}{ Plant species } & \multirow[t]{2}{*}{ Abbr. } & \multicolumn{2}{|c|}{ Ascomycete } & \multicolumn{2}{|c|}{ Coelomycete } & \multicolumn{2}{|c|}{ Anamorphic } & \multicolumn{2}{|c|}{ Non-sporulating } \\
\hline & & $L i$ & En & $\mathrm{Li}$ & En & $\mathrm{Li}$ & En & $\mathrm{Li}$ & $E n$ \\
\hline Dendrocalamus strictus & Dst. (M) & $\overline{1}$ & 3 & $\overline{1}$ & 0 & 28 & 4 & 6 & 1 \\
\hline Bambusa arundinacea & Bar. (M) & 0 & 3 & 1 & 0 & 14 & 3 & 7 & 2 \\
\hline Bauhinia purpurea & Bpu. (D) & 0 & 0 & 5 & 1 & 21 & 3 & 11 & 10 \\
\hline Calamиs thwaitesii & Cth. (M) & 0 & 2 & 1 & 1 & 11 & 3 & 8 & 1 \\
\hline Caryota urens & Cur. (M) & 3 & 0 & 2 & 0 & 13 & 1 & 7 & 6 \\
\hline Curcurma decipens & Cde. (M) & 2 & 1 & 3 & 1 & 12 & 7 & 9 & 5 \\
\hline Dillenia indica & Din. (D) & 0 & 2 & 1 & 1 & 13 & 0 & 16 & 5 \\
\hline Hydnocarpus laurifolia & Hla. (D) & 1 & 2 & 0 & 0 & 14 & 3 & 0 & 4 \\
\hline Terminalia paniculata & Tpa. (D) & 1 & 1 & 1 & 0 & 17 & 2 & 7 & 5 \\
\hline Elaeis guineensis & Egu. (M) & 4 & 0 & 4 & 4 & 33 & 9 & 23 & 10 \\
\hline Ensete superbum & Esu. (M) & 0 & 2 & 1 & 2 & 11 & 2 & 4 & 3 \\
\hline Ficus religiosa & Fre. (D) & 0 & 1 & 0 & 2 & 16 & 2 & 1 & 3 \\
\hline Ficus benghalensis & Fbe. (D) & 0 & 0 & 0 & 2 & 23 & 3 & 10 & 1 \\
\hline $\begin{array}{l}\text { Ficus tinctorius var. } \\
\text { Parasitica }\end{array}$ & Fti.(D) & 2 & 2 & 3 & 1 & 26 & 1 & 17 & 14 \\
\hline Flacourtia montana & Fmo.(D) & 4 & 1 & 2 & 0 & 18 & 2 & 9 & 2 \\
\hline Helictris ixora & Hix. (D) & 2 & 1 & 1 & 0 & 14 & 3 & 10 & 9 \\
\hline Ixora brachiata & Ibr. (D) & 0 & 0 & 1 & 0 & 16 & 21 & 4 & 4 \\
\hline Mangifera indica & Min. (D) & 0 & 1 & 0 & 2 & 12 & 2 & 6 & 2 \\
\hline Pandanus tectorius & Pte. (M) & 0 & 3 & 0 & 0 & 16 & 4 & 24 & 3 \\
\hline Psychotria dalzellii & Pda. (D) & 1 & 2 & 1 & 0 & 14 & 1 & 10 & 4 \\
\hline Sageraea laurifolia & Sla. (D) & 1 & 1 & 0 & 0 & 21 & 0 & 3 & 6 \\
\hline Syzygium cumini & Scu. (D) & 2 & 1 & 3 & 5 & 36 & 6 & 17 & 9 \\
\hline Tectona grandis & Tgr. (D) & 0 & 3 & 2 & 2 & 12 & 5 & 25 & 10 \\
\hline Xylia xylocarpa & Xxy.(D) & 0 & 0 & 3 & 0 & 22 & 2 & 15 & 3 \\
\hline Zanthoxylum rhetsa & Zrh. (D) & 4 & 3 & 1 & 0 & 16 & 3 & 8 & 5 \\
\hline Sanseiviera zeylanica & Sze. (M) & 1 & 0 & 0 & 0 & 16 & 2 & 8 & 6 \\
\hline
\end{tabular}

(Note: Substrates: M-Monocot; D-Dicot; Li- Leaf-litter; En-Endophyte) 


\section{Enzyme Studies}

One hundred and forty species of the litter and endophytic fungi isolated from four test plants, namely, Saraca asoca and Careya arborea (Dicotyledonous plant) and Calamus thwaitesii and Dendrocalamus strictus (Monocotyledonous plant), were screened in order to test their ability to produce at least 3 common enzymes, i.e. amylase, cellulose and pectinase. Of the fungi tested, 10 species were common to both litter and live plant substrates whereas some were either litter inhabiting (67) or endophytic (53) in their substrate relationship.

The results showed that 61 taxa of fungi were positive for amylase (43.57\%), 69 for cellulose $(49.28 \%)$ and 60 for pectinase $(42.85 \%)$ activity. Twenty four species exhibited ability to produce all the enzymes $(17.14 \%)$ whereas a few were found to produce exclusively a particular enzyme, i.e. 13 isolates were amylase positive (9.28\%), 18 cellulolytic (12.86\%) and 23 with pectinolytic activity (16.43\%). Of the 24 taxa with ability to produce all the 3 enzymes, Corynespora sp.2, Corynespora sp.3 and Pestalotiopsis sp. showed highest activity in terms of 'zone of clearance'. Interestingly both these isolates were endophytes.

Some of the fungi which occurred both as litter and endophytes have shown interesting results. (i) Alternaria alternata recovered as an endophyte and litter inhabitant in Saraca asoca exhibited different enzymatic activity; the endophyte derivative was pectinolytic whereas the litter fungus was positive for amylase. (ii) Bharatheeya mucoidea from Calamus thwaitesii as a litter fungus showed positiveness for both amylase and cellulose with significant quantitative difference and further as an endophyte exhibited ability to produce only cellulose. (iii) Exactly similar behavior was shown by Corynespora sp.1 isolated as litter and endophyte fungus, wherein the endophyte showed amylase, cellulose and pectinase activity though of lower level and litter isolates showed positiveness for cellulase. (iv) One more example can be cited with Fusarium solani from the same plant behaving differently in enzyme activity. The litter isolate was positive for amylase and cellulase whereas the endophyte showed both amylase and pectinase activity. It may be inferred that it is a unique phenomenon with Calamus thwaitesii exhibiting distinct substrate specificity in enzyme activity of inhabiting fungi. It is also evident from the study (Table 5) that same species or morphotype when isolated from different plants always behaved differently in their enzyme activity.

The relationship between the fungi studied producing different enzymes was analysed by employing Cluster Analysis (Systat version 5.0) and subjecting the data to 'Euclidean distance average linkage method' (Fig. 3). The result showed that the fungi producing cellulase and amylase were closer compared to pectinase. Similar results were obtained by Miriam (2000) in her studies with 60 isolates of fungi obtained from litter and endophytic substrates of Ficus benghalensis and Carissa congesta.

DISTANCE METRIC IS EUCLIDEAN DISTANCE

COMPLETE LIMKAGE METHOD (FARTHEST MEIGHBOR)

IREE DIAGRAM

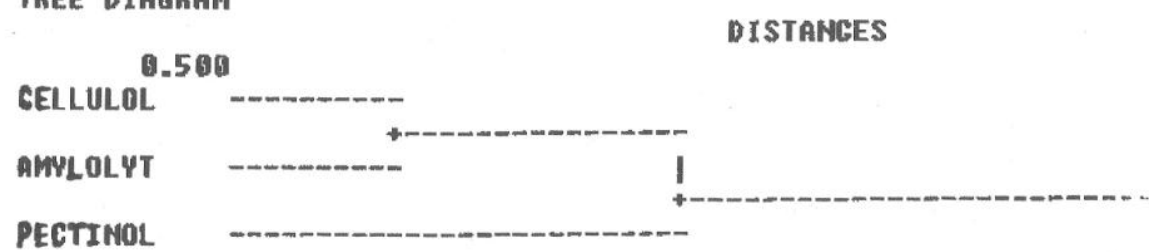

Fig. 3 - Euclidean distance average linkage method 
Table 3 Exclusive genera of microfungi present in the plant species studied

\begin{tabular}{ll}
\hline Name of the fungus & Name of plant species \\
\hline Aquaphila ramdayalea & Flacourtia montana \\
Clonostachys cylindrospora & Syzygium cumini \\
Dictyoarthrinium rabaulense & Dendrocalamus strictus \\
Dictyosporium elegans & Elaeis guineensis \\
Kumbhamaya goanensis & Flacourtia montana \\
Kumbhamaya indica & Dendrocalamus strictus \\
Pseudobeltrania sp. & Bauhinia purpurea \\
Trichobotrys ramosa & Dendrocalamus strictus \\
Zalerion curcumensis & Curcuma decipens \\
\hline
\end{tabular}

An effort was made to analyse the ability of fungi to produce each enzyme qualitatively by observing the clearance zone exhibited by the isolates when grown on enzyme-specific medium. With regard to amylase, the following fungi showed comparatively significant activity by clearance zone measuring more than $1.3 \mathrm{~cm}$; Corynespora sp.2 $(1.6 \mathrm{~cm})$, Pestalotiopsis sp. $(1.5 \mathrm{~cm})$, NSM $(1.6 \mathrm{~cm})$ and Undetermined species $3(1.8 \mathrm{~cm})$. As of cellulase, none of the fungi tested showed significant activity as exhibited by clearance zone measuring more than $1.3 \mathrm{~cm}$. However moderate activity was exhibited by Corynespora $\mathrm{sp} .1(1.1 \mathrm{~cm})$ and $S$ colecobasidium variable $(1.0 \mathrm{~cm})$. The following fungi exhibited pectinolytic activity as exhibited by clearance zone: Cladosporium sp. 9 $(1.3 \mathrm{~cm})$, Trichothecium sp. $(1 \mathrm{~cm})$, NSM 19(1.3cm), NSM $25(1.2 \mathrm{~cm})$ and NSM $31(1.3 \mathrm{~cm})$.

\section{Discussion}

Being one of the megadiversity zones of the world, the forest wealth of Western Ghats have become a matter of considerable interest in the recent days especially the floristic composition. While the higher plant flora of Goa has been worked out in detail (Rao, 1986), there are noteworthy hitherto biodiversity records of terrestrial microfungi from this region (Bhat and Kendrick, 1993; Miriam, 2000; Miriam and Bhat, 2000; Sreekala, 2002, Maria, 2002, Gawas, 2006). This present study is an in-depth and comprehensive elucidation of terrestrial mycota of widely distributed plant species from the forests of Goa.

Some of the workers like Hawksworth, 1991; Subramanian, 1992; Isaac et.al; Rossman, 1994; Bills, 1996; Bills and Polishook, 1994 posed some pertinent questions on species abundance and diversity which remained unanswered. These include 1 . How many species are likely to be found by sampling a single tree or several trees? 2. What and which species are likely to inhabit a particular host plant and what are their relative abundance? With regards to the tropical endophytes extensive work on endophytes of palms was carried (Rodrigues and Samuels, 1990; Rodrigues, 1994; Taylor et al., 1999; Frohlich et al., 2000) and specifically with regards to Indian subcontinent (Bhat and Kendrick, 1993; Suryanarayanan and Kumaresan, 2000; Miriam, 2000; Miriam and Bhat, 2000; Srikala, 2002). With the present study, using different isolation techniques, a large number of fungi could be isolated and brought into pure culture form. It is evident from the results that fungi belonging to hyphomycetous asexual fungi and non-sporulating forms were the major colonizers of the litter of plant species as exhibited by their species abundance. Interestingly in the present study none of the plants scanned were found to be free of endophytes. Similar observations were made on tropical plants by Rodrigues and Samuels (1990). Fisher et al, 1986, Sieber et al., 1991 and Rodrigues, 1994 had earlier reported a high magnitude of undetermined taxa of endophytic fungi from all the plant species studied. The results presented in this paper are in full conformity with this observation. 
Table 4 Jaccard Similarity Coefficient for the litter and endophytic fungi from 4 plant species as expressed in percentage $(\%)$

\begin{tabular}{lllll}
\hline Plant species & Calamus thwaitesii & Saraca asoca & Careya arborea & Dendrocalamus strictus \\
\hline Calamus thwaitesii & 100 & 27.5 & 23.48 & 28.69 \\
Saraca asoca & & 100 & 18.93 & 23.26 \\
Careya arborea & & 100 & 21.19 \\
Dendrocalamus & & & 100 \\
strictus & & & \\
\hline
\end{tabular}

Effort was made in this study to find out the diversity of fungi (litter inhabiting \& endophytes) associated with some of the plant species from the Western Ghat region. A number of fungi (both litter and endophytes) recovered were found common to most of the plant species studied while a few were restricted to specific plants. In this study, not a single fungus was found to occur on all the 30 plant species scanned and only three fungi i.e. Cladosporium herbarum (84.61\%) Cochliobolus lunatus (65.38\%) and Vermiculariopsiella elegans (65.38\%) however showed more than 50\% association with all the plant species (Fig. 2). It may be inferred that vascular plants are the major reservoir of fungi in the forest ecosystem. A few of the fungi were isolated more than once but from the same plant. These were specific to the plant host and did not occur on any other plants. It may be said that, some of the fungi are limited to only one or a few plant species. Such substrate specificity in plants expressed by fungi was predicted by Boddy and Griffith, (1989); Whalley (1993) and the results presented here are in conformity with the earlier work. A large number of microfungi can be occasionally isolated from a single plant species and only a few exhibit dominance in each plant.

\section{Enzyme Studies}

One hundred and forty species of the litter and endophytic fungi isolated from the four tests plants were screened for their ability of producing at least 3 common enzymes, amylase, cellulase and pectinase. The results showed that $17.14 \%$ of the species exhibited ability to produce all the enzymes. Of these, two endophytic forms exhibited highest activity. In general $43.57 \%$ were amylase positive, $49.28 \%$ cellulase and $42.85 \%$ were pectinase positive. It was also evident that a few were producing exclusively a particular enzyme.

Some of the fungi which occurred both as litter and endophytes have shown interesting results. That is, Alternaria alternata behaved differently in its enzyme activity when occurred separately as an endophyte and litter inhabitant in Saraca asoca. Similarly, Bharatheeya mucoidea as a litter fungus showed positiveness for both amylase and cellulase with significant qualitative difference but as an endophyte exhibited ability to produce only cellulase. Similar behavior was shown by Corynespora sp. 1 isolated as litter and endophytic fungus. One more example can be cited with Fusarium solani from the same plant behaving differently in enzyme activity. The litter isolate was positive for amylase and cellulase whereas endophyte showed both amylase and pectinase activity. It may be deduced from this investigation that it is rather a unique phenomenon of fungi where the enzyme activity is dictated by the habit and habitat.

The ability of mycota to grow over a wide range of temperature, $\mathrm{pH}$, moisture content and substrates is the reason for their unique survivability in the decomposing litter and live plant parts and dominance on certain plants. This idea can be taken further to understand the substrate preference in fungi in relation to their host plants. From the results of enzyme analyses it can be interpreted that the occurrence of a fungus in a particular habit and habitat dictated the enzyme activity in that particular fungus. 
Table 5 Qualitative estimation of enzymatic activity of fungi obtained from four study plants: Dendrocalamus strictus; $L$ - Leaf-litter; E-Endophyte)

\begin{tabular}{|c|c|c|c|c|c|}
\hline Fungi & Substrate & Plant sp. & Amylolytic activity & $\begin{array}{c}\text { Cellulolytic } \\
\text { activity }\end{array}$ & $\begin{array}{c}\text { Pectinolytic } \\
\text { activity }\end{array}$ \\
\hline Acremoniella sp. & $\mathrm{E}$ & Cth. & - & - & - \\
\hline Acremonium sp. 1 & $\mathrm{~L}$ & Sas. & + & + & - \\
\hline Acremonium sp. 2 & $\mathrm{~L}$ & Cth. & ++ & - & + \\
\hline Acremonium sp. 3 & $\mathrm{~L}$ & Sas. & + & + & - \\
\hline Acremonium sp. 4 & $\mathrm{~L}$ & Car. & - & + & - \\
\hline Alternaria alternata & $\mathrm{E}$ & Sas. & - & - & + \\
\hline Alternaria alternata & $\mathrm{L}$ & Sas. & + & - & - \\
\hline Ascomycete sp.3 Iso-1 & $\mathrm{E}$ & Sas. & - & - & - \\
\hline Ascomycete sp.4 & $\mathrm{E}$ & Car. & ++ & + & - \\
\hline Ascomycete sp.3 Iso-2 & $\mathrm{E}$ & Car. & - & - & - \\
\hline Bharatheeya mисоidea & $\mathrm{L}$ & Cth. & +++ & + & - \\
\hline Bharatheeya mucoidea & $\mathrm{E}$ & Cth. & - & ++ & - \\
\hline Cladosporium sp. 1 & $\mathrm{~L}$ & Sas. & + & + & - \\
\hline Cladosporium herbarum & $\mathrm{L}$ & Cth. & + & + & + \\
\hline Cladosporium herbarum & $\mathrm{E}$ & Cth. & + & + & + \\
\hline Cladosporium sp. 2 & $\mathrm{~L}$ & Sas. & - & - & - \\
\hline Cladosporium sp. 3 & $\mathrm{~L}$ & Sas. & + & + & - \\
\hline Cladosporium cladosporoides & $\mathrm{E}$ & Den. & + & + & + \\
\hline Cladosporium cladosporoides & $\mathrm{L}$ & Cth. & + & + & + \\
\hline Cladosporium sp. 4 & $\mathrm{~L}$ & Sas. & - & + & - \\
\hline Cladosporium sp. 5 & $\mathrm{~L}$ & Sas. & - & - & - \\
\hline Cladosporium sp. 6 & $\mathrm{~L}$ & Cth. & ++ & + & + \\
\hline Cladosporium sp. 7 & $\mathrm{~L}$ & Car. & - & + & - \\
\hline Cladosporium sp. 8 & $\mathrm{~L}$ & Den. & + & + & - \\
\hline Cladosporium sp.9 & $\mathrm{L}$ & Car. & + & + & +++ \\
\hline Cochliobolus lunatus Iso-1 & $\mathrm{E}$ & Car. & - & ++ & ++ \\
\hline Cochliobolus lunatus Iso-1 & $\mathrm{E}$ & Den. & - & - & - \\
\hline Corynespora sp.1 & $\mathrm{E}$ & Cth. & + & + & + \\
\hline Corynespora sp.1 & $\mathrm{L}$ & Cth. & - & ++ & - \\
\hline Corynespora sp.2 & $\mathrm{E}$ & Den. & +++ & + & ++ \\
\hline Corynespora sp.3 & $\mathrm{E}$ & Cth. & ++ & ++ & + \\
\hline Curvularia lunata & $\mathrm{E}$ & Cth. & + & - & + \\
\hline Cylindrotrichum sp. & $\mathrm{E}$ & Car. & - & + & - \\
\hline Cylindrotrichum sp. & $\mathrm{L}$ & Sas. & - & - & - \\
\hline Dactylella sp. Iso-1 & $\mathrm{L}$ & Cth. & + & + & ++ \\
\hline Dactylella sp. Iso-2 & $\mathrm{L}$ & Sas. & + & - & + \\
\hline Fusarium decemcellulare & $\mathrm{E}$ & Cth. & - & - & + \\
\hline Fusarium decemcellulare & $\mathrm{L}$ & Sas. & + & + & - \\
\hline Fusarium solani & $\mathrm{L}$ & Cth. & + & + & - \\
\hline Fusarium solani & $\mathrm{E}$ & Cth. & + & + & - \\
\hline Idriella lunata & $\mathrm{L}$ & Sas. & ++ & + & - \\
\hline Nigrospora sphaerica & $\mathrm{E}$ & Car. & - & - & + \\
\hline NSM 1 & $\mathrm{~L}$ & Den. & - & + & - \\
\hline NSM 2 & $\mathrm{~L}$ & Den. & - & + & - \\
\hline NSM 3 & $\mathrm{~L}$ & Den. & + & + & + \\
\hline NSM 4 & $\mathrm{E}$ & Den. & + & + & + \\
\hline NSM 5 & $\mathrm{E}$ & Car. & - & - & + \\
\hline NSM 6 & $\mathrm{E}$ & Car. & + & + & + \\
\hline NSM 7 & $\mathrm{E}$ & Car. & ++ & + & + \\
\hline NSM 8 & $\mathrm{E}$ & Car. & +++ & + & - \\
\hline NSM 9 & $\mathrm{E}$ & Car. & + & + & - \\
\hline NSM 10 & $\mathrm{E}$ & Cth. & - & - & - \\
\hline NSM 11 & $\mathrm{E}$ & Den. & - & - & - \\
\hline NSM 12 & $\mathrm{~L}$ & Cth. & - & + & - \\
\hline NSM 13 & $\mathrm{E}$ & Cth. & - & - & - \\
\hline NSM 14 & $\mathrm{E}$ & Den. & + & + & + \\
\hline NSM 15 & $\mathrm{E}$ & Den. & - & + & - \\
\hline NSM 16 & $\mathrm{E}$ & Cth. & - & + & - \\
\hline NSM 17 & $\mathrm{E}$ & Cth. & + & + & + \\
\hline NSM 18 & $\mathrm{~L}$ & Cth. & - & + & ++ \\
\hline NSM 19 & $\mathrm{~L}$ & Cth. & - & ++ & +++ \\
\hline NSM 20 & $\mathrm{~L}$ & Cth. & ++ & + & + \\
\hline NSM 21 & $\mathrm{E}$ & Cth. & ++ & + & + \\
\hline
\end{tabular}




\begin{tabular}{|c|c|c|c|c|c|}
\hline Fungi & Substrate & Plant sp. & Amylolytic activity & $\begin{array}{l}\text { Cellulolytic } \\
\text { activity }\end{array}$ & $\begin{array}{c}\text { Pectinolytic } \\
\text { activity }\end{array}$ \\
\hline NSM 22 & $\mathrm{E}$ & Cth. & - & + & - \\
\hline NSM 23 & $\mathrm{~L}$ & Den. & + & - & - \\
\hline NSM 24 & $\mathrm{E}$ & Car. & + & - & - \\
\hline NSM 25 & $\mathrm{E}$ & Car. & - & - & ++ \\
\hline NSM 26 & $\mathrm{E}$ & Car. & - & + & + \\
\hline NSM 27 & $\mathrm{E}$ & Car. & - & + & + \\
\hline NSM 28 & $\mathrm{~L}$ & Car. & - & - & - \\
\hline NSM 29 & $\mathrm{~L}$ & Car. & - & - & + \\
\hline NSM 30 & $\mathrm{~L}$ & Car. & + & + & - \\
\hline NSM 31 & $\mathrm{~L}$ & Car. & - & - & +++ \\
\hline NSM 32 & $\mathrm{E}$ & Sas. & - & - & ++ \\
\hline NSM 33 & $\mathrm{E}$ & Sas. & - & - & + \\
\hline NSM 34 & $\mathrm{~L}$ & Den. & - & + & - \\
\hline NSM 35 & $\mathrm{E}$ & Sas. & - & - & - \\
\hline NSM 36 & $\mathrm{E}$ & Sas. & - & - & + \\
\hline NSM 37 & $\mathrm{E}$ & Den. & + & - & - \\
\hline NSM 38 & $\mathrm{E}$ & Sas. & - & - & - \\
\hline NSM 39 & $\mathrm{E}$ & Sas. & - & - & + \\
\hline NSM 40 & $\mathrm{E}$ & Sas. & - & - & + \\
\hline NSM 41 & $\mathrm{E}$ & Sas. & - & - & + \\
\hline NSM 42 & $\mathrm{E}$ & Sas. & + & - & + \\
\hline NSM 43 & $\mathrm{E}$ & Sas. & - & - & + \\
\hline NSM 44 & $\mathrm{E}$ & Sas. & - & - & + \\
\hline NSM 45 & $\mathrm{~L}$ & Cth. & - & + & - \\
\hline NSM 46 & $\mathrm{E}$ & Sas. & - & - & + \\
\hline NSM 47 & $\mathrm{E}$ & Sas. & - & - & ++ \\
\hline NSM 48 & $\mathrm{E}$ & Sas. & - & - & - \\
\hline NSM 49 & $\mathrm{E}$ & Sas. & - & - & - \\
\hline NSM 50 & $\mathrm{E}$ & Sas. & - & - & + \\
\hline NSM 51 & $\mathrm{E}$ & Sas. & - & - & - \\
\hline NSM 52 & $\mathrm{E}$ & Sas. & - & - & + \\
\hline NSM 53 & $\mathrm{E}$ & Sas. & - & - & + \\
\hline NSM 54 & $\mathrm{~L}$ & Sas. & - & - & - \\
\hline NSM 55 & $\mathrm{~L}$ & Sas. & ++ & + & - \\
\hline NSM 56 & $\mathrm{~L}$ & Den. & - & - & - \\
\hline NSM 57 & $\mathrm{~L}$ & Sas. & - & - & - \\
\hline NSM 58 & $\mathrm{~L}$ & Sas. & + & - & - \\
\hline NSM 59 & $\mathrm{~L}$ & Sas. & ++ & - & - \\
\hline NSM 60 & $\mathrm{~L}$ & Sas. & + & + & + \\
\hline NSM 61 & $\mathrm{~L}$ & Sas. & - & + & - \\
\hline NSM 62 & $\mathrm{~L}$ & Sas. & - & - & - \\
\hline NSM 63 & $\mathrm{~L}$ & Den. & - & + & + \\
\hline NSM 64 & $\mathrm{~L}$ & Sas. & - & - & - \\
\hline NSM 65 & $\mathrm{~L}$ & Sas. & + & - & - \\
\hline NSM 66 & $\mathrm{~L}$ & Den. & - & + & - \\
\hline NSM 67 & $\mathrm{~L}$ & Sas. & - & - & - \\
\hline NSM 68 & $\mathrm{~L}$ & Sas. & ++ & + & - \\
\hline NSM 69 & $\mathrm{~L}$ & Den. & - & + & - \\
\hline NSM 70 & $\mathrm{~L}$ & Den. & - & - & - \\
\hline NSM 71 & $\mathrm{~L}$ & Sas. & ++ & - & - \\
\hline Penicillum sp.1 & $\mathrm{L}$ & Cth. & + & + & + \\
\hline Penicillum sp.1 & $\mathrm{E}$ & Den. & - & - & - \\
\hline Periconia byssoides & $\mathrm{L}$ & Den. & + & + & + \\
\hline Pestalotiopsis sp. & $\mathrm{E}$ & Car. & +++ & + & + \\
\hline Pestalotiopsis sp. & $\mathrm{L}$ & Sas. & - & + & - \\
\hline Pycnidial fungus & $\mathrm{L}$ & Car. & + & - & - \\
\hline $\begin{array}{l}\text { Scolecobasidium constrictum } \\
\text { Iso-1 }\end{array}$ & $\mathrm{L}$ & Car. & - & - & - \\
\hline $\begin{array}{l}\text { Scolecobasidium constrictum } \\
\text { Iso-2 }\end{array}$ & $\mathrm{L}$ & Cth. & - & - & + \\
\hline $\begin{array}{l}\text { Scolecobasidium constrictum } \\
\text { Iso-3 }\end{array}$ & $\mathrm{L}$ & Cth. & + & - & - \\
\hline Scolecobasidium variable & $\mathrm{L}$ & Cth. & - & ++ & - \\
\hline Stachybotrys nephrospora & $\mathrm{L}$ & Cth. & ++ & + & - \\
\hline Trichothecium $s p$. & $\mathrm{L}$ & Cth. & - & + & ++ \\
\hline Undetermined sp. 1 & $\mathrm{~L}$ & Den. & - & - & - \\
\hline Undetermined sp. 2 & $\mathrm{~L}$ & Sas. & - & - & - \\
\hline
\end{tabular}




\begin{tabular}{lccccc}
\hline Fungi & Substrate & Plant sp. & $\begin{array}{c}\text { Amylolytic activity } \\
\text { Cellulolytic } \\
\text { activity }\end{array}$ & $\begin{array}{c}\text { Pectinolytic } \\
\text { activity }\end{array}$ \\
\hline Undetermined sp. 3 & L & Den. & +++ & - & - \\
Undetermined sp. 4 & E & Sas. & - & - & + \\
Undetermined sp. 5 & L & Sas. & - & - & - \\
Undetermined sp. 6 & E & Cth. & - & ++ & - \\
Undetermined sp. 7 & E & Den. & + & - & + \\
Undetermined sp. 8 & L & Cth. & + & + & - \\
Undetermined sp. 9 & E & Cth. & + & + & + \\
Undetermined sp. 10 & L & Car. & + & - \\
Undetermined sp. 11 & L & Car. & + & + & + \\
Undetermined sp. 12 & L & Car. & ++ & - & - \\
Undetermined sp. 13 & L & Sas. & ++ & + & - \\
Veronaea sp. & L & Den. & - & - & - \\
Wiesneriomyces javanicus & L & Sas. & + & - & + \\
\hline
\end{tabular}

Note: The activity of enzyme as denoted by the clearance zone in $\mathrm{cm}$ :

$0.1-0.6=+$ Low activity; $0.7-1.2=++$ Moderate activity; $1.3-2.0=+++$ Good Activity; $-=$ No Activity

(Note: Substrates: Sas. - Saraca asoca; Cth.- Calamus thwaitesii; Car.- Careya arborea; Den.- Dendrocalamus strictus; L- Leaflitter; $E$-Endophyte)

\section{Acknowledgements}

This work is supported by a research grant to Dr. D. J. Bhat from the Department of Science and Technology, Government of India, New Delhi. One of the author (MD) is thankful for a research fellowship from the Department of Science and Technology, New Delhi.

\section{References}

Alva P, McKenzie EHC, Pointing SB, PenaMuralla R, Hyde KD 2002 - Do Sea grasses harbour endophytes? Fungal Diversity Research Series 7, 167-178.

Arnold AE, Maynard Z, Gilbert, GS, Coley PD and Kursar TA 2000 - Are tropical fungal endophytes hyperdiverse? Ecology Letters 3, 267-274.

Arnold AE 2007 - Understanding the diversity of foliar endophytic fungi: progress, challenges, and frontiers. Fungal Biology Reviews 21, 51-66.

Bhat DJ and Kendrick B 1993 - Twenty-five new conidial fungi from the Western Ghats and the Andaman Islands, India. Mycotaxon 49,19-90.

Bills GF 1995 - Analysis of microfungal diversity from a users perspective. Canadian Journal of Botany 73(1), 33-41.

Bills GF 1996 - Isolation and analysis of endophytic fungal communities from Woody plants. In: Endophytic fungi in grasses and woody plants. Systematics, ecology and evolution (eds. SC Redlin and LM Carris). APS Press, St. Paul, Minnesota. 31-65.

Bills GF and Polishook JD 1991 - Microfungi from Carpinus caroliniana. Canadian Journal of Botany 69, 1477-1482.

Bills GF and Polishook JD 1994 - Abundance and diversity of microfungi in leaf litter of a lowland rain forest in Costa Rica. Mycologia 86, 187-198.

Boddy L and Griffith GS 1989 - Role of endophytes and latent invasion in the development of decay communities in sapwood of angiospermous trees. Sydowia 41, 41-73.

Boddy L and Watkinson SC 1995 - Wood decomposition, higher fungi, and their role in nutrient redistribution. Canadian Journal of Botany 73, 1377-1383.

Carder JH 1986 - Detection and quantitation of cellulase by Congo Red staining of substances in a cup plate diffusion assay. Anal. Biochem. 153, 75-79.

Carmichael JW, Kendrick B, Conners IL and Sigler L 1980 - Genera of Hyphomycetes. University of Alberta Press, Edmonton 1-386.

D'Souza M A and Bhat DJ 2001 - A new species of Trichobotrys from the Western Ghat forests, India. Mycotaxon 80, 105-108. 
D’Souza MA and Bhat DJ 2001 - Two new hyphomycetes from India. In: Microbes and Plants (ed. Aruna Sinha) 1-6.

D'Souza MA and Bhat DJ 2002 - Bharatheeya, a new hyphomycete genus from India. Mycotaxon 83, 397-403.

D'Souza MA and Bhat DJ 2002 - Didymobotryum spirillum, a new synnematous hyphomycete from India. Mycologia 94(3), 535-538.

D’Souza MA and Bhat DJ 2007 - Diversity and abundance of endophytic fungi in four plant species of Western Ghat forest of Goa, southern India. Kavaka 35, 11-20.

Dickinson CH and Wallace V 1976 - Effect of the late applications of the foliar fungicides on activity of micro-organisms on winter wheat flag leaves. Trans. Br. Mycol. Soc. 67, 103112.

Dickinson CH 1976 - Fungi on the aerial surfaces of higher plants. In: Microbiology of aerial plant surfaces (eds. CH Dickinson and TF Preece). Academic Press, New York. 293-324.

Ellis MB 1971 - Dematiatous Hyphomycetes Commonwealth Mycological Institute, Kew, Surrey, England.

Ellis MB 1976 - More Dematiatous Hyphomycetes Commonwealth Mycological Institute, Kew, Surrey, England.

Frohlich J and Hyde KD 1999 - Biodiversity of palm fungi in the tropics: are global fungal diversity estimates realistic? Biodiversity Conservation 8, 977-1004.

Frohlich J, Hyde KD and Petrini O 2000 - Endophytic fungi associated with palms. Mycological Research 104, 1202-1212.

Gary Strobel and Bryn Daisy 2003 - Bioprospecting for Microbial Endophytes and their Natural products. Microbiology and Molecular Biology Reviews. 67(4), 491-502.

Gawas P 2008 - Studies on diversity, activity and ecology of microfungi associated with some medicinal plants of Goa region of Western Ghats, India. Ph.D. Thesis. Goa University.

Ghimire SR and Hyde KD 2004 - Fungal endophytes. In: Plant Surface Microbiology (eds. A Varma, L Abbott, D Werner and R Hampp). Springer Verlag: 281-288.

Gonthier P, Gennaro M and Nicolotti, G 2006 - Effects of water stress on the endophytic mycota of Quercus robur. Fungal Diversity 21, 69-80.

Hankin L and Anagnostakis SL 1975 - The use of solid media for detection of enzyme production by fungi. Mycologia 67, 597-607.

Hawksworth DL 1974 - Mycologist's Handbook. Commonwealth Mycological Institute, Kew, U.K.

Hawksworth DL 1991 - The fungal dimension of biodiversity: magnitude, significance and conservation. Mycological Research 95, 641-655.

Hawksworth DL 1997 - The fascination of fungi: exploring fungal diversity. Mycologist. 11, 1822.

Hyde KD, Bussaban B, Paulus B, Crous PW, Lee S, Mckenzie EHC, Photita W and Lumyong S 2007 - Biodiversity of saprobic fungi. Biodiversity and Conservation 16, 17-35.

Hyde KD and Soytong K 2008 - The fungal endophyte dilemma. Fungal Diversity. 33, 163-173.

Isaac S, Frankland JC, Watling R and Whalley AJS - 1993 Aspects of tropical mycology. Cambridge University Press, Cambridge, U.K.

Jennings DH 1995 - Physiology of Fungal Nutrition. Cambridge University Press, New York.

Jennings DH 1989 - Some perspectives on nitrogen and phosphorous metabolism in fungi. In Boddy, L., R. Marchant \& D. J. Read (eds), Nitrogen, Phosphorus and Sulphur Utilisation by Fungi. Cambridge University Press, Cambridge. 1-31.

Keshavaprasad TS, Maria D, and Bhat DJ 2003 - Vermiculariopsiella Bender: Present Status of Species Diversity. In: Frontiers of Fungal Diversity in India (Prof. Kamal Festschrift). (eds. GP Rao, C Manoharachari, DJ Bhat, RC Rajak and TN Lakhanpal). International Book Distributing Co. Lucknow, India, 503-511. 
Kjøller A and Struwe S 1992 - Functional groups of microfungi in decomposition. In Caroll, G. C. \& D. T. Wicklow (eds), The Fungal Community: Its Organization and Role in the Ecosystem, 2nd ed. Marcel Dekker Inc, New York. 619-630.

Li WC, Zhou J, Guo SY and Guo LD 2007 - Endophytic fungi associated with lichens in Baihua mountain of Beijing, China. Fungal Diversity 25, 69-80.

Maria. AD and Bhat DJ 2002 - Kramasamuha kamalensis, sp. nov. from India. Journal of Basic and Applied Mycology 1(1), 6-7

Maria AD and Bhat DJ 2012 - A new species of Pleurophragmium from India. Mycotaxon. 119, 477- 482. http://dx.doi.org/10.5248/119.477.

Matsushima T 1971 - Microfungi of Solomon Islands and Papua-New Guinea. Matsushima. Kobe, Japan.

Matsushima, T. 1975 - Icones Microfungorum A Matsushima Lectorum. Matsushima. Kobe, Japan.

Mille-Lindblom C, Fischer H and Tranvik LJ 2006 - Litter-associated bacteria and fungi - a comparison of biomass and communities across lakes and plant species. Freshwater Biology $51,730-741$

Miriam J 2000 - Studies on diversity, ecology and activity of the microfungi associated with Ficus bengalensis Linn. and Carissa congesta Wight from Goa State. Ph.D. Thesis. Goa University, India.

Moore-Landecker E 1996 - Fundamental of the Fungi, 4th ed. Prentice-Hall, New Jersey.

Oses R, Valenzuela S, Freer J, Sanfuentes E and Rodriguez J 2008 - Fungal endophytes in xylem of healthy Chilean trees and their possible role in early wood decay. Fungal Diversity 33, 77-86.

Petrini O and Fisher PJ 1986 - Fungal endophytes in Salicornia perennis. Trans. Br. Mycol. Soc. 87, 647-651.

Petrini O 1986 - Taxonomy of endophytic fungi in aerial plant tissues. In: Microbiology of the phyllosphere. (eds. NJ Fokkema and J Van den Heuvel). Cambridge University Press. Cambridge. 175-187.

Rao SS 1986 - Flora of Goa, Diu, Daman, Dadra and Nagarhaveli. Vol. I and II. Botanical Survey of India, New Delhi.

Redlin SC and Carris LM 1996 - Endophytic Fungi in Grasses and Woody Plants. APS Press, Minnesota.

Rodrigues KF and Samuels GJ 1990 - Preliminary study of endophytic fungi in tropical palm. Mycol. Res., 94, 827-830.

Rodrigues KF 1994 - Foliar fungal endophytes of the Amazonian palm Euterpe oleracea. Mycologia, 86, 376-385.

Rodrigues KF and Petrini KF 1997 - Biodiversity of endophytic fungi in Tropical regions. In: Biodiversity of Tropical Microfungi. (ed. Hyde, K.D.) Hongkong University Press, Hong Kong.

Rossman AY 1994 A strategy for an all taxa inventory of Fungal biodiversity and terrestrial ecosystems. (eds. C.J. Peng and C.H. Chou). Institute of Botany, Academia Sinica No. 14, 169-194.

Sánchez Márquez S, Bills GF and Zabalgogeazcoa I 2007 - The endophytic mycobiota of the grass Dactylis glomerata. Fungal Diversity 27, 171-195.

Sneath PHA and Sokal RR 1973 - Numerical Taxonomy. W.H. Freeman, San Francisco.

Nair SK 2002 - Studies on Diversity, Ecology and Biology of microfungi from freshwater streams of Western Ghats in Goa State, India. Ph.D. Thesis. Goa University.

Subramanian CV 1992 - Tropical mycology and biotechnology. Current Science 63, 167-172.

Suryanarayan TS and Kumaresan V 2000 - Endophytic fungi of some halophytes from an estuarine mangrove forest. Mycological Research 104, 1465-1467.

Sutton BC 1980 The Coelomycetes: Fungi Imperfectii with Pycnidia, Acervuli and Stromata. Commonwealth Mycological Institute, U.K. 
Taylor JE and Hyde KD 2003 - Microfungi on Tropical and Temperate Palms. Fungal Diversity Research Series 12, 1-459.

Whalley AJS 1993 - Tropical Xylariaceae: their distribution and ecological characteristics. In: Aspects of tropical mycology (eds. S Isaac, JC Frankland, R Watling and AJS Whalley), Cambridge University Press: Cambridge, U.K. pp. 103-120.

Zhou D and Hyde KD 2001 - Host-specificity, host-exclusivity, and host-recurrence in saprobic fungi. Mycological Research 105, 1449-1457. 